\title{
ANALISIS DAYA SAING DENGAN MENGGUNAKAN DESTINATION COMPETITIVENESS MODEL (Studi pada Heritage Tourism di Jawa)
}

\author{
Edriana Pangestuti \\ Fakultas Ilmu Administrasi Universitas Brawijaya \\ email:edrianap@yahoo.co.id
}

\begin{abstract}
This study sought to understand the relationship between destination competitiveness factors (such as the tourist's image, service quality, satisfaction) and behavioral intention. Little empirical research has explored these relationships from the heritage tourist's perspective. A mixed method was used to achieve the study's objectives and test the conceptual model. Twelve in-depth interviews and 400 questionnaire surveys (international and domestic) were conducted using purposive technique sampling. A structural equation modeling (SEM) technique was applied to identify, evaluate and develop the dimensions and test the relationship between these dimensions simultaneously. The final model showed that service quality has a significant relationship with satisfaction but an insignificant relationship with behavioral intention. In addition, this study provided new insights, determining that destination image and service quality factors influence destination competitiveness via the mediating of tourists' satisfaction in a heritage tourism context. This shows the importance of destination image and service quality for measuring competitiveness. This present model will be useful as a guide for future research for measuring destination competitiveness in the heritage tourism context. Understanding destination competitiveness factors will help marketers predict future travel behavior and develop effective strategies in order to compete with other destinations.
\end{abstract}

Keywords: destination image, satisfaction, service quality, behavioral intention and destination competitiveness

\begin{abstract}
ABSTRAK
Penelitian ini berusaha memahami hubungan antara faktor daya saing destinasi (seperti citra destinasi, kualitas layanan, kepuasan) dan niat perilaku. Beberapa penelitian serupa telah dilakukan dengan melihat dari perspektif wisatawan. Metode kualitatif dan kuantitatif (Mix method) digunakan untuk menguji model konseptual. Dua belas narasumber dan 400 kuesioner (wisatawan internasional dan domestik) digunakan dalam penelitian ini dengan teknik purposive sampling. Teknik pemodelan persamaan struktural (SEM) diterapkan untuk mengidentifikasi, mengevaluasi dan mengembangkan dimensi dan menguji hubungan antara dimensi ini secara bersamaan. Model akhir menunjukkan bahwa kualitas pelayanan memiliki hubungan yang signifikan dengan kepuasan namun terdapat hubungan yang tidak signifikan pada niat perilaku. Selain itu, penelitian ini memberikan wawasan baru, menunjukkan bahwa citra destinasi dan faktor kualitas layanan mempengaruhi daya saing destinasi melalui mediasi kepuasan wisatawan. Hal ini menunjukkan pentingnya citra destinasi dan kualitas layanan untuk mengukur daya saing. Model sekarang ini akan berguna sebagai panduan untuk penelitian selanjutnya untuk menganalisis lebih mendalam mengenai daya saing destinasi dalam konteks pariwisata sejarah. Memahami faktor daya saing destinasi akan membantu pelaku industry pariwisata memprediksi perilaku wisatawan dan mengembangkan strategi yang efektif agar dapat bersaing dengan destinasi lain.
\end{abstract}

Kata kunci: citra destinasi, kepuasan, kualitas layanan, perilaku wisatawan dan daya saing destinasi 


\section{PENDAHULUAN}

Pariwisata adalah industri penting yang memberikan kontribusi signifikan terhadap anggaran nasional dan lokal. Pada saat ini pariwisata dianggap sebagai salah satu industri terbesar di dunia. Industry ini membawa dampak pada sektor bisnis seperti hotel, restoran, penerbangan dan agen perjalanan. The World Travel and Tourism Council (WTTC) juga menyatakan bahwa pariwisata telah tumbuh lebih cepat dari kebanyakan kegiatan ekonomi lainnya, dan akan terus tumbuh kuat, dapat menciptakan lapangan kerja dan meningkatkan Produk Domestik Bruto (PDB). Pangsa pasar negara berkembang meningkat dari 30\% pada tahun 1980 menjadi $45 \%$ pada 2013, dan diperkirakan akan mencapai 57\% pada tahun 2030, setara dengan lebih dari satu miliar kedatangan wisatawan internasional (UNWTO 2014).

\section{Perkembangan Heritage Tourism}

Timotius dan Nyaupane (2009a) menyatakan bahwa pertumbuhan heritage tourism diperkirakan memiliki prospek yang lebih baik daripada jenis wisata lainnya. Pedersen (2002) dalam United Nations Educational, Scientific, and Cultural Organization (UNESCO) mengkategorikan heritage tourism dalam dua bidang: warisan budaya dan warisan alam. Timothy (2011) juga diklasifikasikan ke dalam warisan alam dan budaya. Heritage tourism sangat berguna untuk menarik semakin banyak wisatawan datang ke suatu destinasi. Hal ini penting untuk meningkatkan citra destinasi (destination image) dan menciptakan brand destination. Harish (2014) juga berpendapat bahwa destination image telah membuat India menjadi lebih dikenal dan diterima sebagai tempat tujuan wisata. Dalam proses globalisasi, meningkatnya minat suatu destinasi dan destination branding adalah faktor kunci yang telah memberikan kontribusi terhadap peningkatan daya saing (Cai 2002, Gartner, 1986, Konecnik dan Gartner, 2007, Murphy et al., 2007). Suatu destinasi akan bersaing melalui image/citra yang terpatri di benak wisatawan (Baloglu dan McCleary, 1999).

Indonesia memiliki potensi untuk dikembangkan lebih lanjut sebagai tempat tujuan wisata heritage karena memiliki banyak atraksi warisan alam dan budaya. Indonesia memiliki banyak pulau dengan karakteristik budaya dan alam yang unik (BPS, 2012). Seperti dicatat oleh Badan Pusat Statistik (BPS) (2012), 10 tempat tujuan wisata di Indonesia adalah Bali, Jawa Barat, Jawa Tengah, Jawa Timur, Jakarta, Sumatera Utara, Lampung, Sulawesi Selatan, Sumatera Selatan, Banten dan Sumatera Barat. Jawa adalah destinasi yang paling populer dengan berbagai pilihan wisata heritagenya. Jawa terdapat beragam produk wisata alam, sejarah, dan agama. Jawa juga memiliki beberapa lokasi wisata heritage yang telah diklasifikasikan oleh UNESCO sebagai situs warisan dunia.

Jumlah wisatawan asing yang datang ke Jawa Timur pada periode Januari-April 2013 meningkat secara signifikan. Secara kumulatif, meningkat sebesar $15,8 \%$ dibandingkan dengan periode yang sama di tahun 2012. Pariwisata masih didominasi oleh pengunjung dari Malaysia dengan kontribusi 3.828 wisatawan, 1.383 wisatawan dari Singapura dan 1.151 wisatawan dari China (BPS, 2013c). Sementara itu di Jawa Tengah, pada periode Januari-April 2013, terdapat 5.218 wisatawan yang juga didominasi oleh pengunjung dari Malaysia, Perancis, dan Singapura (BPS, 2013b). Di Jakarta terdapat 162.668 wisatawan internasional terutama dari Malaysia, Cina, dan Jepang (BPS, 2013a). Meningkatnya jumlah wisatawan tersebut menjadi indikator meningkatnya minat wisatawan menjadikan Jawa sebagai tujuan wisata. Untuk mencapai jumlah pengunjung yang semakin meningkat, Pemerintah dan industri wisata yang terkait harus meningkatkan kualitas pelayanan, sarana dan prasarana pariwisata dan mengembangkan strategi yang efektif sehingga Jawa dapat bersaing dengan negara-negara tetangga.

\section{Destination Competitiveness}

Pertumbuhan persaingan industri pariwisata yang semakin pesat membuat suatu 
destinasi harus terus meningkatkan berbagai fasilitas untuk memenuhi kebutuhan wisatawan, serta menemukan cara untuk mempromosikan tempat-tempat wisata (Hudson et al., 2004b). Chen et al. (2011a) menganalisis dan menyarankan bahwa nilai, persepsi dan keunikan peninggalan sejarah dapat digunakan sebagai objek untuk menarik wisatawan. Dwyer (2003) menjelaskan competitiveness adalah sebagai faktor yang paling penting dalam mengembangkan industri pariwisata untuk menjadi destinasi yang sukses. Untuk menarik wisatawan, industri pariwisata harus fokus pada daya saing tujuan wisata (destination competitiveness). Memahami indicatorindikator pariwisata yang kompetitif dapat mempengaruhi keputusan seorang wisatawan "apakah dia akan mengunjungi suatu destinasi atau tidak". Ritchie dan Crouch (2000) mendefinisikan destination competitiveness sebagai kemampuan untuk menciptakan nilai sehingga dapat meningkatkan kesejahteraan lokal dan nasional dengan mengelola asset menjadi lebih baik dan mengintegrasikan hubungan tersebut menjadi model ekonomi dan sosial. Mereka menunjukkan bahwa mengukur destination competitiveness, atraksi dan sumber daya adalah faktor penentu (utama) dalam mempromosikan pariwisata. Mereka menemukan bahwa destination image, yang terdiri dari sumber daya dan keindahan alam adalah faktor utama dalam mengukur destination competitiveness.

Destination competitiveness dapat ditingkatkan dengan kerjasama yang tepat antara destination resources dan atraksi, perencanaan strategis yang tepat dan peningkatan upaya strategi daya saing (Crouch dan Ritchie 1999, Gomezelj dan Mihalic 2008, Yoon et al., 2001). Crouch dan Ritchie (1999) menyatakan bahwa untuk membuat destinasi yang kompetitif, kualitas pelayanan yang baik dan pengalaman yang memuaskan sangat dibutuhkan untuk menarik wisatawan. Oleh karena itu, untuk mencapai daya saing wisata, sebuah kolaborasi yang baik antara strategi pemasaran dan manajemen harus dikembangkan (Cracolici et al., 2008, Al-
Masroori, 2006a). Chen et al. (2011a) menyatakan bahwa destination competitiveness dapat ditingkatkan dengan meningkatkan atraksi destinasi yang tepat dan kinerja pelayanan untuk memuaskan pelanggan, mendorong mereka untuk tidak hanya meninjau kembali tujuan tetapi juga merekomendasikan hal ini kepada orang lain. Semakin positif image suatu destinasi, semakin besar manfaat yang akan diperoleh destinasi tersebut. Image/ citra suatu destinasi adalah faktor yang paling penting karena mempengaruhi tingkat kepuasan serta perilaku setelahnya termasuk didalamnya word-of-mouth dan kunjungan berikutnya. Dengan demikian, pengalaman positif wisatawan akan pelayanan, produk dan sumber daya lain yang disediakan oleh destinasi wisata adalah sangat penting (Yuksel, 2007). Rekomendasi dari wisatawan yang telah berkunjung ke destinasi dapat dijadikan sebagai sumber informasi yang paling handal untuk calon wisatawan berikutnya (Chi dan Qu, 2008). Oleh karena itu indurti pariwisata harus meningkatkan image destinasi mereka untuk lebih menarik minat wisatawan mengunjungi destinasi. Image yang positif mengenai objek wisata heritage secara khusus diyakini menghasilkan hal yang positif untuk destination competitiveness (Timotius dan Nyaupane, 2009a). Keunikan destinasi juga dapat menarik wisatawan. Oleh karena itu, dengan memahami image destinasi, kontribusi positif terhadap kepuasan wisata dan daya saing destinasi akan diperoleh (Dwyer dan Kim, 2003). Dengan demikian manajer wisata harus menggali keunggulan-keunggulan kompetitif suatu destinasi dan menganalisis daya saing destinasi.

Penelitian ini bertujuan untuk mengeksplorasi peran heritage tourism dalam konteks destination competitiveness di Jawa. Lebih mendasar, penelitian ini mengkaji factor-faktor yang mempengaruhi destination competitiveness dari 'perspektif' wisatawan (demand side) seperti yang telah diusulkan oleh Dwyer dan Kim (2003), Crouch et al. (2011) dan Chen 2011) untuk memposisikan Jawa sebagai tempat tujuan wisata heritage. 
Penelitian ini akan membantu dalam mengembangkan strategi yang efektif sehingga Java dapat bersaing dengan destinasi lainnya seperti Singapura, Malaysia dan Thailand.

\section{Rumusan Masalah}

Penelitian ini berusaha untuk memahami hubungan antara faktor-faktor daya saing destinasi (seperti image, kualitas pelayanan, kepuasan) dan niat perilaku. Pemahaman yang lebih baik dari dampak image tujuan dan kualitas pelayanan terhadap kepuasan dan behavior intention akan memberikan informasi ke dalam daya saing destinasi dalam konteks wisata heritage. Sampai saat ini, hanya sedikit penelitian empiris yang mengeksplorasi hubungan tersebut dari perspektif heritage tourism. Penelitian ini menemukan gab/ kesenjangan dengan menganalisis fenomena baik secara konseptual dan empiris. Kesenjangan tersebut adalah sebagai berikut:

1. Tidak adanya penelitian tentang faktor daya saing destinasi wisata dalam konteks heritage tourism. Konsep daya saing destinasi (destination competitiveness) belum dianalisis dalam konteks heritage tourism, khususnya di Jawa.

2. Kurangnya penelitian tentang faktor daya saing destinasi dari sisi permintaan (demand side). Mayoritas penelititan yang telah dilakukan mengukur daya saing destinasi dari sisi suplai (supply side).

3. Tidak ada studi empiris yang menganalisis pengaruh kualitas pelayanan dan kepuasan terhadap perilaku konsumen (behavior) dari perspektif heritage tourism dan destination competitiveness. Belum ada model daya saing destinasi yang komprehensif yang telah dikembangkan untuk meneliti hubungan antara image wisata, kualitas layanan, kepuasan dan niat perilaku dalam konteks heritage tourism.

\section{Tujuan Penelitian}

1. Untuk menyelidiki pentingnya destination image dan kualitas layanan untuk heritage tourism dari sisi permintaan (demand side).

2. Untuk menguji perbedaan antara dua jenis wisatawan (domestik dan internasional) dalam kaitannya dengan image, kualitas layanan, kepuasan, dan niat perilaku.

3. Untuk mengetahui pengaruh destination image dan kualitas layanan pada tingkat kepuasan dan perilaku wisatawan dalam konteks heritage tourism.

4. Untuk melakukan studi banding daya saing wisata heritage antara Jawa dan tujuan heritage lainnya.

5. Untuk menguji model daya saing destinasi yang diusulkan, dengan fokus pada faktorfaktor yang mempengaruhi daya saing wisata destinasi dalam konteks heritage tourism di Jawa.

\section{KERANGKA KONSEPTUAL}

Kerangka konseptual penelitian ini didasarkan dari model daya saing destinasi pariwisata yang dikembangkan oleh peneliti sebelumnya (Dwyer dan Kim 2003, Ritchie dan Crouch 2000, Enright dan Newton 2004, Lee dan Raja, 2009, Kozak et al., 2010a, Ritchie dan Crouch, 2003a). Faktor-faktor penentu daya saing destinasi termasuk dalam kerangka konseptual adalah: destination image (sumber inti), kualitas layanan (faktor dan sumber daya pendukung), kepuasan wisatawan, dan perilaku wisatawan (Crouch 2011, Gilbert dan Churchill, 1979).

Model yang dikembangkan berisi variabel dan kategori seperti yang diidentifikasi oleh Dwyer dan Kim (2010), Crouch (2011) dan Chen et al. (2010) dalam kerangka komprehensif mengenai destination competitiveness mereka. Variabelvariabel tersebut adalah: 
Table 1. Destination Competitiveness Models

\begin{tabular}{|c|c|c|c|}
\hline Dwyer (2003) & Chen (2011) & Crouch (2011) & This research \\
\hline Resources (natural & Resources and & Supporting resources & Resources (natural \\
and cultural) & service performance & $\downarrow$ & and cultural) and \\
$\downarrow$ & $\downarrow$ & Core resources & service quality \\
Destination & Tourists' satisfaction & $\downarrow$ & $\downarrow$ \\
management & $\downarrow$ & Destination & Tourists' satisfaction \\
$\downarrow$ & Destination & management & $\downarrow$ \\
Destination & competitiveness & $\downarrow$ & Behavioural intention \\
competitiveness & & Destination policy & $\downarrow$ \\
& & $\downarrow$ & Destination \\
& & Destination & competitiveness \\
& & & \\
& & competitiveness & \\
\hline
\end{tabular}

Source: (Dwyer and Kim, 2003, Chen et al., 2011b, Crouch, 2011).

Dari Table 1. tersebut diatas dapat disimpulkan bahwa Dwyer (2003) dan Crouch (2011) memfokuskan pada destination image dan kualitas pelayanan sebagai faktor daya saing tetapi tidak mengukur kepuasan wisatawan. Sementara Chen et al. (2011b) fokus pada kepuasan wisatawan dan menyatakan bahwa untuk membuat satu destinasi lebih populer dan menarik daripada yang lain, citra/image wisatawan yang positif terhadap kualitas pelayanan adalah sangat penting. Chen et al. (2011b) mengukur dampak dari kinerja pelayanan pada kepuasan wisatawan tetapi tidak menganalisis destination image sebagai faktor penting untuk mengukur destination competitiveness.

Oleh karena itu, penelitian ini bertujuan untuk mengembangkan model konseptual tersebut dengan menggunakan destination image, kualitas pelayanan, kepuasan wisatawan dan niat perilaku (behavior intention sebagai factor yang mempengaruhi destination competitiveness, dengan mengintegrasikan tiga model yang telah dikembangkan oleh Dwyer dan Kim (2003), Ritchie dan Crouch (2011) dan Chen et al. (2011b). Kerangka konseptual disajikan di bawah ini.

\section{Figure 1 Heritage Tourism Competitiveness Model}

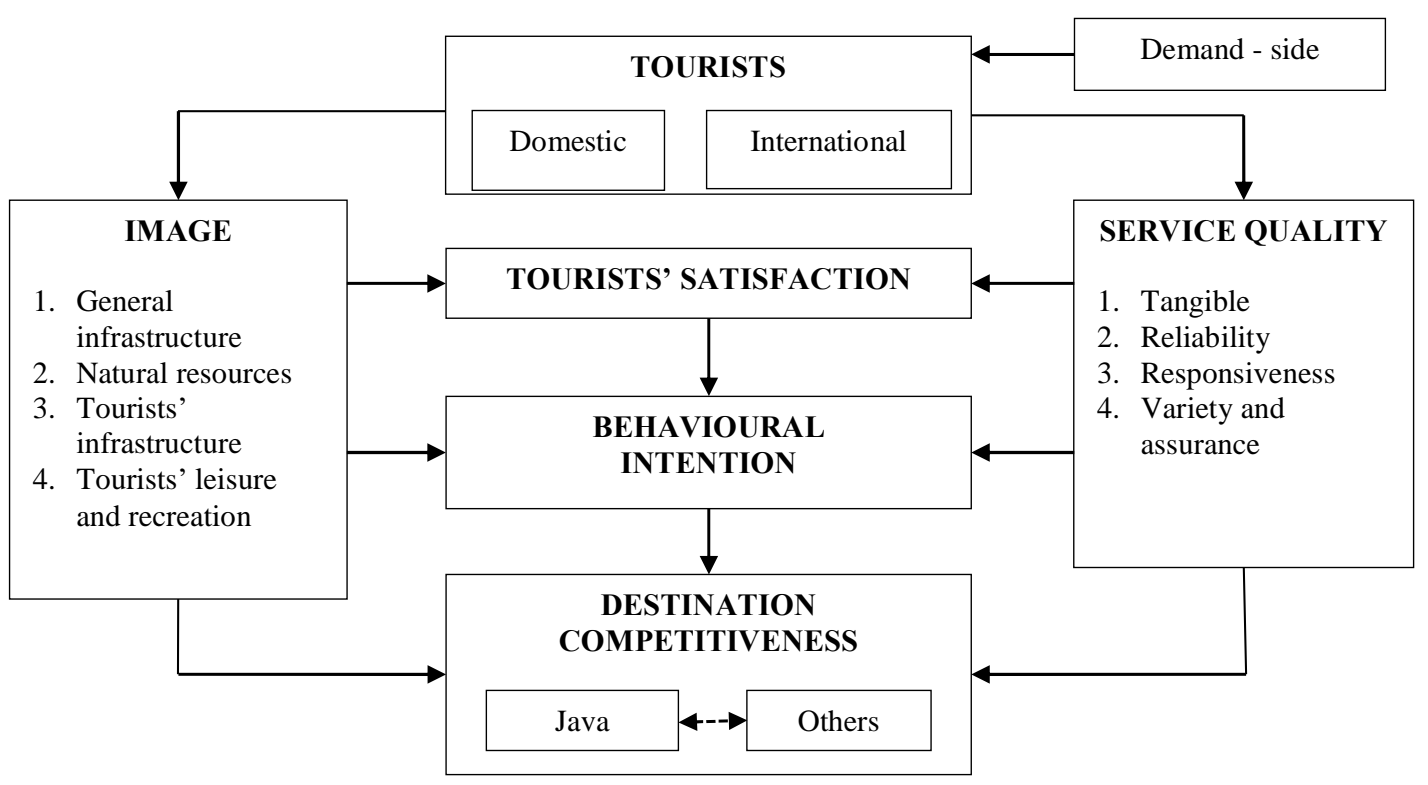

Source: Developed by the researcher.

Oleh karena itu, berdasarkan research objective dan kerangka konseptual tersebut diatas dapat dikembangkan menjadi 12 Hypotesis : hypothesis $1-5$ berkaitan dengan pengujian 
descriptive yaitu menguji perbedaan persepsi dua grup wisatawan terhadap image, kualitas layanan, kepuasan, perilaku dan destination competitiveness. Sedangkan hypothesis $6-12$ berkaitan dengan pengujian model yaitu untuk mengetahui hubungan antar variable yang mempengaruhi destinationcompetitiveness.

\section{METODE PENELITIAN}

Untuk mencapai tujuan penelitian dan untuk menguji model konseptual, metode campuran (mixed method) kualitatif dan kuantitatif diaplikasikan dalam penelitian ini. Metode kualitative menggunakan 12 pelaku pariwisata sebagai sampel. Tujuannya adalah untuk mengetahui factor-faktor apa saja yang dapat mempengaruhi wisatawan untuk memilih destinasi sebagai tempat berlibur mereka. Sedangkan metode kuantitative menggunakan 400 wisatawan sebagai sampel yang terbagi menjadi wisatawan internasional dan domestic. Tehnik sampling yang digunakan adalah purposive dan accidental sampling. Tehnik analisis yang digunakan dalam penelitian ini meliputi descriptive analisis dipergunakan untuk menganalisis profil wisatawan. T-test diterapkan untuk menguji perbedaan rata-rata (mean) antara persepsi wisatawan domestik dan internasional terkait dengan factor-faktor yang mempengaruhi destination competitiveness dalam konteks heritage tourism di Jawa.

Sedangkan tehnik analisis berikutnya adalah untuk menguji model konseptual, sebuah pemodelan persamaan struktural (SEM) teknik diterapkan untuk mengidentifikasi, mengevaluasi dan mengembangkan dimensi dan menguji hubungan antara dimensi-dimensi ini secara simultan.

\section{HASIL DAN PEMBAHASAN}

Dari total 400 wisatawan, diketahui $65 \%$ adalah wisatawan laki-laki dan $35 \%$ adalah wisatawan wanita dengan proporsi wisatawan laki-laki mancanegara $36 \%$ lebih besar dibandingkan dengan wisatawan dalam negeri yaitu $29 \%$. Sementara wisatawan wanita lebih didominasi oleh wisatawan dalam negeri (21\%). Hampir setengah dari total wisatawan berusia antara $32-47$ tahun, $42 \%$ untuk yang berusia 16 - 31 tahun, dan $9 \%$ untuk yang berusia antara $48-66$ tahun. Berkaitan dengan pendapatan, sebagian besar wisatawan berpenghasilan 50 juta - 80 juta pertahun. Hal ini memungkinkan bagi mereka untuk menyisihkan sebagian pendapatan mereka untuk berwisata. Semakin besar pendapatan/penghasilan yang dimiliki, semakin besar pula kemungkinan bagi mereka untuk menyisihkan uang mereka untuk berwisata (Kang dan Hsu, 2005).

Dalam kuisioner, latar belakang pendidikan wisatawan dikelompokkan menjadi lima. Hasil menunjukkan bahwa mayoritas wisatawan memiliki latar belakang pendidikan sarjana (90\%). Hasil tersebut konsisten dengan penelitian yang telah dilakukan oleh McKercher and Du Cros (2002) dan Timothy dan Nyaupane (2009a) yang menyatakan bahwa pendidikan memiliki korelasi dengan harapan mereka berwisata. Berkaitan dengan status, wisatawan dalam negeri didominasi oleh wisatawan yang sudah menikah sedangkan wisatawan mancanegara banyak yang berstatus single.

\section{Tourists' Travel Patterns}

Wisatawan mancanegara berasal dari Eropa, Asia, Amerika dan Asia Pasifik. Kebanyakan dari mereka didominasi oleh wisatawan dari Belanda, Perancis dan Jerman.

\section{Trip Length}

Hampir 70\% wisatawan (dalam negeri dan mancanegara) melakukan kunjungan wisata (berlibur) tidak lebih dari 5 malam.

\section{Travel Arrangement}

Hampir 60\% wisatawan melakukan pemesanan perjalanan wisata dengan menggunakan tour organiser, $15 \%$ wisatawan melakukan pemesanan secara terpisah dan $27 \%$ wisatawan tidak melakukan pemesanan secara khusus. 


\section{Travel Composition}

$40 \%$ wisatawan berwisata secara individu (sendiri), 30\% wisatawan berwisata dengan keluarga/pasangan, $20 \%$ dengan teman dan 5\% dengan grup. $26 \%$ wisatawan mancanegara lebih senang melakukan perjalanan wisata sendiri sedangkan wisatawan dalam negeri (34\%) lebih senang berwisata dengan keluarga mereka.

\section{Purpose to Visit}

$22 \%$ wisatawan dalam negeri dan $23 \%$ wisatawan mancanegara mengunjungi Jawa untuk berlibur, bertemu dengan sanak (11\%), bisnis (4\%), sekolah (3\%), sport event (3\%), dan tujuan lainnya (5\%). Wisatawan mancanegara mengunjungi Jawa untuk menikmati festival budaya (10.5\%), sekolah dan mengunjungi keluarga (8\%), adventure (4\%), dan untuk tujuan lainnya (4\%).

\section{Domestic Tourists}

1. A good shopping place

2. A variety of flora and fauna

3. Variety of recreation activities

wisatawan dalam negeri menganggap Jawa adalah destinasi yang cocok untuk berbelanja, banyak terdapat aneka ragam flora dan fauna serta memiliki banyak tempat wisata yang menarik lainnya. Sementara bagi wisatawan mancanegara, Jawa adalah destinasi yang terkenal dengan keanekaragaman flora dan faunanya, merupakan destinasi yang aman dan tempat yang cocok untuk berbelanja.

\section{Tourist Attractions}

Bagi wisatawan dalam negeri dan mancanegara, Jawa Barat dan Jawa Timur lebih menarik dengan wisata alamnya. Bogor Botanical Garden dan taman nasional Bromo adalah wisata alam yang paling banyak dikunjungi disbanding destinasi yang lain. Sementara Jawa tengah lebih terkenal dengan wisata budayanya yaitu adanya Candi Borobudur dan Prambanan yang dinobatkan oleh UNESCO sebagai situs peninggalan sejarah terbesar didunia.

Differences in Destination Images between Domestic and International Tourists

Hypothesis 1: "Statistically significant differences in images exist between domestic and international heritage tourists in Java" was supported by the data.

\section{International Tourists}

1. A variety of flora and fauna

2. Safety

3. A good shopping place

\section{Differences in Service Quality between Domestic and International Tourists}

Hasil penelitian menunjukkan bahwa Hypothesis 2: "Statistically significant differences in service quality exist between domestic and international heritage tourists in Java" adalah didukung oleh data.
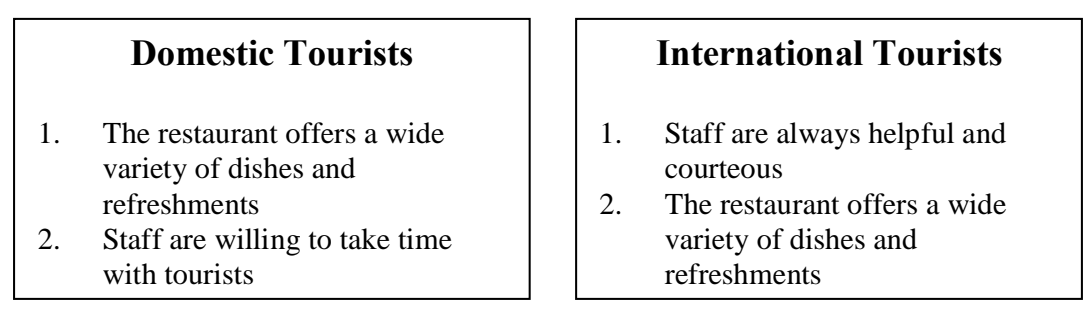

Diagram diatas menunjukkan bahwa semua wisatawan baik domestic maupun mancanegara, keanekaragaman jenis menu makanan dan pelayanan staff hotel menjadi prioritas mereka dalam menilai kualitas layanan selama mereka berwisata.

Difference in Tourists' Satisfaction and Behavioural Intention 
Kedua kelompok wisatawan merasa puas dengan heritage tourism yang ada di Jawa. Hal tersebut terlihat dari nilai mean $=4.280$ untuk wisatawan dalam negeri dan mean $=4.145$ untuk wisatawan mancanegara dengan perbedaan mean antara keduanya sebesar $\mathrm{d}=0.135$. oleh karena itu Hypothesis 3: "Statistically significant differences in tourists' satisfaction exist between domestic and international heritage tourists in Java" terbukti. Sedangkan hasil penelitian yang bekaitan dengan perilaku wisatawan (behaviour intention), kedua grup wisatawan tersebut adalah akan "recommend Java to others". Hal ini mendukung Hypothesis 4: "Statistically significant differences in behavioural intention exist between domestic and international heritage tourists in Java".

\section{Domestic Tourists}

1. Good shopping opportunity

2. Traditional arts

3. Security/safety for tourists

\section{Java's Destination Competitiveness}

Hasil penelitian menunjukkan adanya perbedaan yang signifikan antara wisatawan domestic dan mancanegara tentang Jawa. Hal ini mendukung Hypothesis 5: "Statistically significant differences in competitiveness exist between domestic and international heritage tourists in Java". Wisatawan domestic menganggap Jawa lebih menarik dibanding dengan destinasi lainnya yaitu dalam hal: tempat berbelanja, traditional art dan keamanannya. Sementara bagi wisatawan mancanegara, Jawa lebih menarik dalam hal: scenery, historic/heritage sites dan keanekaragaman kegiatan wisatanya.

\section{Pengujian Model (SEM analisis)}

Hasil pengujian menunjukkan bahwa terdapat banyak hubungan antar variable. Destination image tidak hanya berpengaruh terhadap kepuasan konsumen, tetapi juga berpengaruh terhadap perilaku konsumen dan destination

\begin{tabular}{|ll|}
\hline \multicolumn{1}{|c|}{ International Tourists } \\
1. & Scenery \\
2. & Historic/Heritage sites \\
3. & A wide range of tourist activities \\
\hline
\end{tabular}

layanan hanya berpengaruh pada tingkat kepuasan konsumen dan kepuasan konsumen berpengaruh terhadap destination competitiveness.

Untuk lebih jelasnya dapat dilihat dalam Tabel 2 berikut ini: competitiveness. Sementara itu kualitas

\begin{tabular}{|c|c|c|c|c|c|c|c|}
\hline & & & Estimate & S.E. & C.R. & $\mathrm{P}$ & Result \\
\hline $\begin{array}{l}\text { Tourists' } \\
\text { satisfaction }\end{array}$ & $<--$ & Destination image & .163 & .069 & 2.373 & .018 & $\mathbf{S}$ \\
\hline $\begin{array}{l}\text { Tourists' } \\
\text { satisfaction }\end{array}$ & $<---$ & Service quality & .517 & .100 & 5.171 & $* * *$ & $\mathbf{S}$ \\
\hline $\begin{array}{l}\text { Behavioural } \\
\text { intention }\end{array}$ & $<---$ & Destination image & .685 & .154 & 4.434 & $* * *$ & $\mathbf{S}$ \\
\hline $\begin{array}{l}\text { Behavioural } \\
\text { intention }\end{array}$ & $<---$ & Tourists'satisfaction & .319 & .193 & 1.655 & .098 & NS \\
\hline $\begin{array}{l}\text { Behavioural } \\
\text { intention }\end{array}$ & $<---$ & Service quality & .061 & .193 & .317 & .751 & NS \\
\hline $\begin{array}{l}\text { Destination } \\
\text { competitiveness }\end{array}$ & $<---$ & Service quality & .042 & .113 & .367 & .714 & NS \\
\hline $\begin{array}{l}\text { Destination } \\
\text { competitiveness }\end{array}$ & $<---$ & $\begin{array}{l}\text { Behavioural } \\
\text { intention }\end{array}$ & .029 & .040 & .731 & .465 & NS \\
\hline $\begin{array}{l}\text { Destination } \\
\text { competitiveness }\end{array}$ & $<---$ & $\begin{array}{l}\text { Tourists' } \\
\text { satisfaction }\end{array}$ & .378 & .129 & 2.927 & .003 & $\mathbf{S}$ \\
\hline $\begin{array}{l}\text { Destination } \\
\text { competitiveness }\end{array}$ & $<--$ & Destination image & .236 & .093 & 2.524 & .012 & $\mathbf{S}$ \\
\hline
\end{tabular}

Tabel 2 diatas menunjukkan bahwa Hypotheses 6, 7, 8 and 11 adalah diterima, sementara Hypotheses 9, 10 and 12 adalah ditolak. Penelitian ini membuktikan bahwa destination image memiliki pengaruh yang signifikan pada kepuasan dan perilaku 
konsumen. Sementara itu kualitas layanan hanya berpengaruh positif pada kepuasan konsumen tetapi tidak berpengaruh positif pada perilaku (behaviour intention). Selain itu ditemukan juga hubungan yang signifikan antara destination image dan kepuasan konsumen terhadap destination competitiveness. Sementara kualitas layanan tidak memiliki hubungan yang signifikan terhadap destination competitiveness. Akan tetapi hubungan yang tidak signifikan antara kualitas layanan terhadap perilaku konsumen dan destination competitiveness dapat dimediasi dengan variable kepuasan konsumen. Sehingga dapat diambil kesimpulan bahwa destination image dengan didukung dengan kualitas pelayanan yang baik merupakan factor terpenting untuk mengukur destination competitiveness.

\section{KESIMPULAN DAN SARAN}

\section{Kesimpulan}

Wisatawan domestik dan internasional setuju bahwa Jawa adalah suatu destinasi yang memiliki heritage site yang sangat menarik dan secara keseluruhan mereka puas dengan sarana dan prasarana yang tersedia di Jawa. Penelitian ini telah berhasil mengembangkan model konseptual yang komprehensif dan holistik yang meneliti faktor-faktor yang mempengaruhi destination competitiveness dalam konteks heritage tourism. Temuan penelitian ini menunjukkan adanya hubungan timbal balik antara faktor-faktor tersebut Temuan ini menunjukkan bahwa wisatawan (domestik dan mancanegara) menganggap bahwa image suatu destinasi merupakan faktor terpenting dalam mengukur destination competitiveness daripada kualitas layanan.

\section{Implikasi Managerial}

- Penelitian ini telah menunjukkan bahwa Jawa memiliki potensi alam dan budaya untuk dijadikan sebagai tempat tujuan wisata selain ke 3 daerah wisata yang menjadi fokus pemerintah. Oleh karena itu perencanaan pembangunan secara hati-hati sangat diperlukan dalam memanfaatkan potensi tersebut.

- Penelitian ini mampu mengeksplorasi faktor-faktor penentu daya saing destinasi untuk mengembangkan strategi, kerangka kerja dan pedoman manajemen untuk pengembangan masa depan sektor pariwisata heritage di Jawa. Dari perspektif sisi permintaan (demand side), hasil ini memiliki implikasi bagi para pembuat kebijakan publik untuk berusaha menciptakan lingkungan investasi yang positif dan untuk mencapai tujuan jangka panjang yang keberlanjutan dan diferensiasi tujuan dengan menerapkan strategi positioning dan branding

- Keunikan yang dimiliki Jawa serta penerapan branding strategi diharapkan dapat memposisikan Jawa sebagai sebuah pulau yang memiliki keindahan eksotis alam, budaya yang unik, berbagai macam makanan yang terkenal, lingkungan yang bersih, adat istiadat yang menarik dan harga yang bersaing. Oleh karena itu, pemerintah harus memperkuat image dan meminimalkan resiko.

\section{Suggestion for Future Research}

Diharapkan model daya saing suatu destinasi (destination competitiveness) ini dapat diterapkan/ berlaku di seluruh destinasi di dunia, terutama di berbagai tujuan wisata di Asia yang memiliki karakteristik yang relatif sama dengan Jawa. Dikarenakan penelitian ini lebih menekankan pada penelitiaan kuantitatif, diharapkan untuk penelitian selanjutnya dapat melakukan penelitian dengan metode kualitatif. Penelitian selanjutnya diharapkan untuk menganalisis destination competitiveness dengan menggunakan demografi responden sebagai attribute untuk menilai. Diharapkan juga untuk peneliti selanjutnya melakukan penelitian dari sisi produsen (supply side). 


\section{DAFTAR PUSTAKA}

AL-MASROORI，R. S. 2006b. Destination Competitiveness: Interrelationships between destination planning and development strategies and stakeholders' support in enhancing Oman's tourism industry. Unpublished doctoral dissertation). Griffith University, Australia.

BALOGLU, S. \& MCCLEARLY, K. W. 1999. A model of destination image formation. Annals of Tourism Research, 26, 868-897.

Badan Pusat Statistik 2012. Indonesia Tourism Prospect. Jakarta,Indonesia.

Badan Pusat Statistik. 2013a. The development of tourism and national transportations in Indonesia [Online]. Jakarta, Indonesia: BPS.

CAI, L. A. 2002. Cooperative branding for rural destinations. Annals of Tourism Research, 29, 720-742.

CHEN, C. M., CHEN, S. H. \& LEE, H. T. 2011b. The destination competitiveness of Kinmen's tourism industry: exploring the interrelationships between tourist perceptions, service performance, customer satisfaction and sustainable tourism. Journal of Sustainable Tourism, 19, 247-264.

CHI, C. G. Q. \& QU, H. 2008. Examining the structural relationships of destination image, tourist satisfaction and destination loyalty: An integrated approach. Tourism Management, 29, 624-636.

CRACOLICI, M. F., NIJKAMP, P. \& RIETVELD, P. 2008. Assessment of tourism competitiveness by analysing destination efficiency. Tourism Economics, 14, 325-342.

CROUCH, G. I. \& RITCHIE, J. R. B. 1999. Tourism, Competitiveness and Societal prosperity. Journal of Business Research, 44, 137-152.

DWYER, L. \& KIM, C. 2003. Destination competitiveness: determinants and indicators. Current issues in tourism, 6, 369-414.
GARTNER, W. C. 1986. Temporal influences on image change. Annals of Tourism Research, 13, 635-644.

GARTNER, W. C. 1994. Image formation process. Journal of Travel \& Tourism Marketing, 2, 191-216.

GOMEZELJ, D. O. \& MIHALIC, T. 2008. Destination competitiveness-Applying different models, the case of Slovenia. Tourism Management, 29, 294-307.

HUDSON, S., RITCHIE, B. \& TIMUR, S. 2004a. Measuring destination competitiveness: An empirical study of Canadian ski resorts. Tourism and Hospitality Planning \& Development, 1, 79-94.

KANG, S. K. \& HSU, C. H. 2005. Dyadic consensus on family vacation destination selection. Tourism Management, 26, 571-582.

KONECNIK, M. \& GARTNER, W. C. 2007. Customer-based brand equity for a destination. Annals of Tourism Research, 34, 400-421.

KOZAK, M., BALOGLU, S. \& BAHAR, O. 2010b. Measuring Destination Competitiveness: Multiple Destinations Versus Multiple Nationalities. Journal of Hospitality Marketing \& Management, 19, 56-71.

MURPHY, L., MOSCARDO, G. \& BENCKENDORFF, P. 2007. Using brand personality to differentiate regional tourism destinations. journal of Travel Research, 46, 5-14.

RITCHIE, J. R. B. \& CROUCH, G. I. 2000. The competitive destination, a sustainable perspective. Tourism Management, 21, 1-7.

TIMOTHY , D. J. 2011. Cultural Heritage and Tourism: An Introduction, Toronto, Channel View Publications.

UNWTO. 2008. Tourist 2020 vision [Online]. http://www.unwto.org/facts/eng/vision htm.

YOON, Y. \& UYSAL, M. 2005b. An examination of the effects of motivation and satisfaction on 
destination loyalty: a structural model. Tourism Management, 26, 45-56.

YUKSEL, A. 2007. Tourist shopping habitat: Effects on emotions, shopping value and behaviours. Tourism Management, 28, 58-69. 